ISSN: 2302-8556

E-Jurnal Akuntansi Universitas Udayana

Vol.27.3.Juni (2019): 2183-2210

DOI: https://doi.org/10.24843/EJA.2019.v27.i03.p20

\title{
Faktor-Faktor yang Berpengaruh pada Kualitas Audit
}

\author{
Wawan Rosdiana ${ }^{1}$ \\ I G.A.M. Asri Dwija Putri \\ ${ }^{1,2}$ Fakultas Ekonomi dan Bisnis Universitas Udayana (Unud), Bali, Indonesia \\ e-mail: wawan_rosdiana@yahoo.com
}

\begin{abstract}
ABSTRAK
Permasalahan mengenai rendahnya kualitas audit menjadi sorotan masyarakat dalam beberapa tahun terakhir. Hal ini disebabkan karena keterlibatan dari akuntan publik di dalamnya. Penelitian ini bertujuan untuk mengetahui pengaruh independensi, due professional care dan akuntabilitas terhadap kualitas audit. Penelitian ini dilaksanakan di KAP di Kota Denpasar yang terdaftar pada IAPI tahun 2018. Sampel dipilih dengan menggunakan teknik sampel jenuh. Data dikumpulkan melalui penyebaran kuesioner kepada auditor dan teknik analisis data yang digunakan adalah regresi linier berganda. Hasil penelitian dengan uji statistik $\mathrm{t}$ menunjukkan bahwa secara parsial independensi, due professional care dan akuntabilitas berpengaruh positif dan signifikan terhadap kualitas audit pada Kantor Akuntan Publik di Kota Denpasar.
\end{abstract}

Kata kunci: Independensi, due professional care, akuntabilitas

\begin{abstract}
Problems regarding the low level of audit quality have become the focus of the public in recent years. This is due to the involvement of public accountants in it. This study aims to determine the effect of independence, due professional care and accountability on audit quality. This research was conducted in the Public Accounting Firm in Denpasar, which was registered with IAPI in 2018. The sample was selected using a saturated sample technique. Data was collected through questionnaires to auditors and data analysis techniques used were multiple linear regression. The results of the study with $t$ statistical tests showed that partially independence, due professional care and accountability had a positive and significant effect on audit quality at the Public Accounting Firm in the City of Denpasar.
\end{abstract}

Keywords: Independence, due professional care, accountability

\section{PENDAHULUAN}

Laporan keuangan memberikan informasi kinerja perusahaan yang diperlukan sebagai sarana pengambilan keputusan baik oleh pihak internal maupun pihak eksternal perusahaan. Laporan keuangan yang telah diaudit oleh akuntan publik, lebih dapat dipercaya dibandingkan laporan keuangan yang tidak atau belum diaudit. 
Laporan keuangan yang telah diaudit dapat digunakan oleh para pengambil keputusan dengan keyakinan bahwa informasi yang terkandung di dalamnya relevance dan reliable, serta berguna sebagai pedoman perbaikan oleh manajemen dan perusahaan. Laporan audit tidak hanya berfokus pada hal - hal yang bersifat angka, namun juga berkaitan dengan aspek manajerial perusahaan.

Menurut Financial Accounting Standard Board (FASB), dua karakteristik terpenting yang harus ada dalam laporan keuangan adalah relevan (relevance) dan dapat diandalkan (reliable). Kedua karakteristik tersebut sangatlah sulit untuk diukur, sehingga para pemakai informasi membutuhkan jasa pihak ketiga yaitu akuntan publik untuk untuk menilai kewajaran informasi keuangan yang disajikan oleh manajemen.

Akuntan publik tidak hanya bertanggungjawab kepada klien, namun juga untuk pihak lain yang berkepentingan terhadap laporan keuangan hasil audit, yaitu calon investor, investor, kreditor, masyarakat, dan pihak lain yang terkait untuk menilai dan mengambil keputusan-keputusan strategis yang berhubungan dengan perusahaan. Sebuah perusahaan dalam hal ini sangat membutuhkan jasa audit, khususnya bagi perusahaan-perusahaan yang sudah go public. Dalam hal ini tentunya diharapkan audit yang dihasilkan adalah audit yang berkualitas.

Kualitas audit merupakan segala kemungkinan dimana auditor pada saat mengaudit laporan keuangan klien dapat menemukan pelanggaran yang terjadi dalam sistem akuntansi klien dan melaporkannya dalam bentuk laporan keuangan auditan, 
ISSN: 2302-8556

dimana dalam melaksanakan tugasnya tersebut auditor berpedoman pada standar audit dan kode etik akuntan publik yang relevan (Agusti dan Pertiwi, 2013).

Oleh karena itu sangat penting bagi seorang auditor independen untuk menjaga kualitas audit agar dapat tercipta kepercayaan publik terhadap keakuratan dan validitas laporan keuangan yang telah diaudit. Akan tetapi profesi seorang auditor telah menjadi sorotan sejak munculnya banyak kasus audit yang melibatkan akuntan publik yang menimbulkan keraguan publik terhadap kualitas audit, sehingga integritas dan objektivitas para akuntan publik sudah mulai diragukan oleh pihak yang berkepentingan atas laporan akuntan publik akibat dari maraknya kasus audit yang terjadi akhir-akhir ini. Sebagai contoh, kasus pada kantor akuntan publik mitra Ernst \& Young's (EY) di Indonesia, yakni Kantor Akuntan Publik (KAP) Purwantono, Suherman \& Surja sepakat membayar denda senilai US\$ 1 juta (sekitar Rp 13,3 miliar) kepada regulator Amerika Serikat, akibat divonis gagal melalukan audit laporan keuangan kliennya. Temuan itu berawal ketika kantor akuntan mitra EY di AS melakukan kajian atas hasil audit kantor akuntan di Indonesia. Mereka menemukan bahwa hasil audit atas perusahaan telekomunikasi itu tidak didukung dengan data yang akurat, yakni dalam hal persewaan lebih dari 4 ribu unit tower selular. Namun Kantor Akuntan Publik (KAP) Purwantono, Suherman \& Surja merilis laporan hasil audit dengan status wajar tanpa pengecualian.

Selain kasus Kantor Akuntan Publik (KAP) Purwantono, Suherman \& Surja, ada juga kasus yang dimuat di media online www.wartaekonomi.co.id (Priantara, 2017) isu terjadinya fraud akuntansi di British Telecom. Perusahaan raksasa Inggris 
ini mengalami fraud akuntansi di salah satu lini usahanya di Italia. Sebagaimana skandal fraud akuntansi lainnya, fraud di British Telecom berdampak kepada akuntan publiknya. Tidak tanggung-tanggung, kali ini yang terkena dampaknya adalah Price Waterhouse Coopers $(\mathrm{PwC})$ yang merupakan kantor akuntan publik ternama di dunia dan termasuk the big four. Modus fraud akuntansi yang dilakukan British Telecom di Italia sebenarnya relatif sederhana dan banyak dibahas di literatur kuliah auditing namun banyak auditor gagal mendeteksinya yakni melakukan inflasi (peningkatan) atas laba perusahaan selama beberapa tahun dengan cara tidak wajar melalu kerja sama koruptif dengan klien-klien perusahaan dan jasa keuangan.

Satu lagi kasus di sektor keuangan yang dimuat dalam media online https://tirto.id yaitu kasus perusahaan multifinance PT. Sunprima Nusantara Pembiayaan (SNP Finance) diketahui merugikan 14 bank di Indonesia hingga triliunan rupiah. Dalam kasus ini Otoritas Jasa Keuangan (OJK) menjatuhkan sanksi administratif kepada dua akuntan publik (AP) dan satu kantor akuntan publik (KAP). Pangkal soalnya, AP Marlinna dan AP Merliyana Syamsul serta KAP Satrio, Bing, Eny (SBE) dan Rekan dinilai tidak memberikan opini yang sesuai dengan kondisi sebenarnya dalam laporan keuangan tahunan audit milik PT. Sunprima Nusantara Pembiayaan (Syafina, 2018).

AP Marlinna, AP Merliyana Syamsul, KAP Satrio, Bing, Eny (SBE) dan Rekan yang merupakan partner lokal Deloitte Indonesia dianggap melanggar POJK Nomor 13/POJK.03/2017 tentang Penggunaan Jasa Akuntan Publik dan Kantor Akuntan Publik. Pertimbangannya adalah OJK menilai AP Marlinna dan AP 
ISSN: 2302-8556

E-Jurnal Akuntansi Universitas Udayana

Vol.27.3.Juni (2019): 2183-2210

Merliyana Syamsul telah melakukan pelanggaran berat sehingga melanggar POJK Nomor 13/POJK.03/2017 Tentang Penggunaan Jasa Akuntan Publik dan Kantor Akuntan Publik. Ini sebagaimana tertera dalam penjelasan Pasal 39 huruf b POJK Nomor 13/POJK.03/2017, bahwa pelanggaran berat yang dimaksud antara lain AP dan KAP melakukan manipulasi, membantu melakukan manipulasi, dan atau memalsukan data yang berkaitan dengan jasa yang diberikan.

Pengenaan sanksi terhadap dua AP dan KAP oleh OJK itu diberikan lantaran Laporan Keuangan Tahunan Audit (LKTA) yang diaudit tersebut selanjutnya digunakan oleh PT. SNP Finance untuk mendapatkan kredit dari perbankan dan menerbitkan surat utang jangka pendek (medium term notes/MTN) yang berpotensi mengalami gagal bayar dan atau menjadi kredit bermasalah.

Berdasarkan kasus yang terjadi pada akuntan publik tersebut mempengaruhi persepsi masyarakat, khususnya para pemakai laporan keuangan yang sangat mengharapkan laporan keuangan auditan yang berkualitas. Terkait dengan kasus inilah sehingga muncul pertanyaan seberapa besar pengaruh tingkat independensi, due professional care dan akuntabilitas seorang auditor terhadap kualitas audit dalam pemeriksanaan laporan keuangan. Dalam hal ini, kantor akuntan publik (KAP) perlu meningkatkan kualitas audit untuk meningkatkan integritas auditor agar kembali dapat dipercaya pihak yang berkepentingan dengan memperhatikan independensi, due professional care dan akuntabilitas.

Independensi adalah sikap yang diharapkan dari seorang akuntan publik untuk tidak mempunyai kepentingan pribadi dalam melaksanakan tugasnya, yang 
bertentangan dengan prinsip integritas dan objektivitas sesuai dengan Kode Etik Akuntan Publik. Standar umum auditing kedua mengharuskan auditor untuk bersikap independen dan tidak dibenarkan untuk memihak yaitu bahwa "Dalam semua hal yang berhubungan dengan perikatan, independensi dalam sikap mental harus dipertahankan oleh auditor" (Ikatan Akuntan Indonesia, 2001:150.1). Penelitian Imron dkk., (2017) menghasilkan bahwa independensi auditor berpengaruh positif dan signifikan terhadap kualitas hasil audit investigasi. Hal ini didukung penelitian (Badjuri, 2011) yang dalam penelitiannya menghasilkan independensi berpengaruh positif signifikan pada kualitas audit. Hasil penelitian ini bersesuaian dengan hasil penelitian Usman et.al., (2014) dan Hosseinniakani et al., (2014) dalam penelitiannya menyatakan bahwa independensi berpengaruh terhadap kualitas audit. Namun hasil sebaliknya diberikan penelitian Sukriah dkk., (2009), dan Kovinna dan Betri (2009) yang menjelaskan bahwa independensi tidak berpengaruh signifikan terhadap kualitas audit.

Due professional care dapat diartikan sebagai kemahiran profesional yang cermat dan seksama, dilaksanakan oleh seseorang (standar umum ketiga (SA seksi 230 dalam SPAP, 2001). Dengan sikap cermat, auditor akan mampu mengungkap berbagai macam kecurangan dalam penyajian laporan keuangan lebih mudah dan cepat. Dalam SPAP No. 4 (Ikatan Akuntan Indonesia, 2001) juga disebutkan kecermatan dan keseksamaan dalam penggunaan kemahiran profesional menuntut auditor untuk melaksanakan skeptisme profesional yaitu sikap auditor yang berpikir kritis terhadap bukti audit dengan selalu mempertanyakan dan melakukan evaluasi 
ISSN: 2302-8556

terhadap bukti audit tersebut. Louwers, et.al (2008) menyatakan bahwa kegagalan audit dalam kasus fraud transaksi pihak-pihak terkait disebabkan oleh kurangnya sikap skeptis dan due professional care auditor daripada kekurangan dalam pemenuhan standar auditing. Hasil penelitian Nearon (2005) dalam Mansur (2007) menyatakan bahwa jika auditor gagal dalam menggunakan sikap skeptis atau penerapan sikap skeptis yang tidak sesuai dengan kondisi pada saat pemeriksaan, maka opini audit yang diterbitkannya tidak berdaya guna dan tidak memiliki kausalitas audit yang baik. Penelitian (Bawono \& Singgih, 2010) menghasilkan bahwa due professional care berpengaruh terhadap kualitas audit. Demikian juga penelitian Faturachman (2015) mengemukakan due professional care berpengaruh positif terhadap kualitas audit. Hasil sebaliknya ditunjukkan dalam penelitian Nugraha (2012) dan Purwaningsih dkk., (2015) bahwa due professional care tidak berpengaruh signifikan terhadap kualitas audit.

Akuntabilitas merupakan wujud kewajiban seseorang untuk mempertanggungjawabkan pengelolaan atas kewenangan yang dipercayakan kepadanya guna pencapaian tujuan yang ditetapkan. Nugrahaningsih (2005) menyatakan bahwa akuntan memiliki kewajiban untuk menjaga standar perilaku etis tertinggi mereka kepada organisasi dimana mereka berlindung, profesi mereka, masyarakat dan pribadi mereka sendiri dimana akuntan mempunyai tanggung jawab menjadi kompeten dan berusaha menjaga integritas dan obyektifitas mereka. Hasil penelitian ini sejalan dengan hasil penelitian yang dilakukan oleh Mardisar dan Sari (2007) menyatakan bahwa akuntabilitas dapat meningkatkan kualitas hasil kerja 
auditor. Namun hasil berbeda ditunjukkan oleh penelitian akuntabilitas auditor tidak memiliki pengaruh terhadap kualitas audit.

Audit merupakan suatu proses yang sistematik untuk memperoleh dan mengevaluasi bukti secara obyektif mengenai pernyataan-pernyataan tentang kegiatan dan kejadian ekonomi, dengan tujuan untuk menetapkan tingkat kesesuaian antara pernyataan-pernyataan tersebut dengan kriteria yang telah ditetapkan, serta penyampaian hasil-hasilnya kepada pemakai yang berkepentingan. Ditinjau dari sudut profesi akuntan publik, audit adalah pemeriksaan secara obyektif atas laporan keuangan suatu perusahaan atau organisasi lain dengan tujuan untuk menentukan apakah laporan keuangan tersebut menyajikan secara wajar, dalam semua hal yang material, posisi keuangan, dan hasil usaha perusahaan atau organisasi tersebut.

Dalam memberikan pendapat mengenai kewajaran laporan keuangan yang diperiksa, akuntan publik harus mempertahankan sikap mental independen di dalam memberikan jasa profesional sebagaimana diatur dalam standar profesional akuntan publik yang ditetapkan oleh IAI (Ikatan Akuntan Indonesia), baik untuk kepentingan klien, para pemakai laporan keuangan, maupun terhadap kepentingan akuntan publik itu sendiri.

Mautz dan Sharaf, (1980) menyatakan independensi merupakan sikap auditor yang bebas serta tidak memihak dalam melaksanakan audit. Mulyadi, (2014:111) menyebutkan independen memberikan arti adanya kejujuran pada diri auditor dalam mempertimbangkan fakta yang diperoleh serta bersikap objektif tidak memihak dalam menyatakan pendapatnya. 
ISSN: 2302-8556

Menurut Gavious (2007) kepentingan auditor guna memenuhi keinginan klien yang telah membayar jasa auditor membuat sulitnya memihak sehinga auditor cenderung kehilangan independensinya. Independensi auditor seringkali terganggu karena auditor menerima bayaran dari klien atas jasa yang diberikan kepadanya sehingga auditor cenderung memenuhi keinginan klien.

Independensi merupakan suatu standar auditing yang sangat penting untuk dimiliki oleh auditor. Auditor harus dapat mempertahankan sikap mental independen karena opini yang dikeluarkannya bertujuan untuk menambah kredibilitas laporan keuangan yang disajikan manajemen, sehingga jika auditor tersebut tidak independen maka kualitas audit yang dihasilkan tidak baik.

Due professional care memiliki arti kemahiran profesional yang cermat dan seksama. Auditor harus menggunakan keahlian profesionalnya dengan cermat dan seksama (due professional care) dan secara hati-hati (prudent) dalam setiap penugasan. Due professional care dapat diterapkan dalam pertimbangan profesional (professional judgment), meskipun dapat saja terjadi penarikan kesimpulan yang tidak tepat ketika audit sudah dilakukan dengan seksama.

Auditor harus menggunakan keahlian profesionalnya dengan cermat dan seksama (due professional care) dan secara hati-hati (prudent) dalam setiap penugasan. Penerapan kecermatan dan keseksamaan diwujudkan dengan dilakukannya review secara kritis pada setiap tingkat supervisi terhadap pelaksanaan audit. Kecermatan dan keseksamaan menyangkut apa yang dikerjakan auditor dan bagaimana kesempurnaan pekerjaan yang telah dihasilkan. Kecermatan dan 
keseksamaan auditor yang jujur dituntut agar aktivitas audit dan perilaku profesional tidak berdampak merugikan orang lain. Due professional care menjadi hal yang penting yang harus diterapkan oleh setiap akuntan publik dalam melaksanakan pekerjaan profesionalnya agar tercapai kualitas audit yang memadai.

Penelitian Imron dkk., (2017) menghasilkan bahwa independensi auditor berpengaruh positif dan signifikan terhadap kualitas hasil audit investigasi. Hal ini didukung penelitian (Badjuri, 2011) yang dalam penelitiannya menghasilkan independensi berpengaruh positif signifikan pada kualitas audit. Hasil penelitian ini bersesuaian dengan hasil penelitian Tepalagul dan Lin (2015), Usman et al., (2014) dan Hosseinniakani et al., (2014) dalam penelitiannya menyatakan bahwa independensi berpengaruh terhadap kualitas audit. Namun tidak demikian dengan hasil penelitian yang dilakukan Prabhawanti dan Widhiyani (2018) yang menunjukkan independensi berpengaruh negatif dan tidak signifikan pada kualitas audit, hal ini juga bersesuaian dengan penelitian Sukriah dkk., (2009) dan Kovinna dan Betri (2009) yang memberi hasil bahwa independensi tidak berpengaruh signifikan terhadap kualitas audit.

Independensi yang dimiliki oleh auditor itu sendiri tidak menjamin audit yang dihasilkan berkualitas, dikarenakan kurangnya sikap independensi yang dimiliki oleh auditor dan tidak ingin kehilangan klien maka auditor mengikuti kemauan dari klien itu sendiri agar tidak kehilangan. Dari penjelasan dan hasil penelitian tersebut di atas, hipotesis pertama yang dapat diajukan adalah:

H1 : Independensi berpengaruh positif terhadap kualitas audit 
ISSN: 2302-8556

Due professional care dapat diartikan sebagai kemahiran profesional yang cermat dan seksama, dilaksanakan oleh seseorang. (Bawono \& Singgih, 2010) dalam penelitiannya menghasilkan bahwa due professional care berpengaruh terhadap kualitas audit. Demikian juga penelitian Faturachman (2015) mengemukakan due professional care berpengaruh positif terhadap kualitas audit. Hal ini didukung juga oleh hasil penelitian Ichwanty (2015) namun hasil sebaliknya ditunjukkan dalam penelitian Nugraha (2012) dan Purwaningsih dkk., (2015) bahwa due professional care tidak berpengaruh signifikan terhadap kualitas audit.

H2 : Due professional care berpengaruh positif terhadap kualitas audit

Akuntabilitas merupakan wujud kewajiban seseorang untuk mempertanggungjawabkan pengelolaan atas kewenangan yang dipercayakan kepadanya guna pencapaian tujuan yang ditetapkan. Hasil penelitian Purwanda dan Harahap, (2015) tentang pengaruh akuntabilitas dan kompetensi terhadap kualitas audit, membuktikan akuntabilitas berpengaruh dalam memberikan perubahan yang berarti terhadap kualitas audit. Mardisar dan Sari (2007) menyebutkan tanggung jawab (akuntabilitas) auditor dalam melaksanakan audit akan mempengaruhi kualitas audit yang dihasilkan.

H3 : akuntabilitas berpengaruh positif terhadap kualitas audit

\section{METODE PENELITIAN}

Penelitian ini dilaksanakan di Kantor Akuntan Publik (KAP) di Kota Denpasar yang terdaftar sebagai anggota Institut Akuntansi Publik Indonesia (IAPI) tahun 2018 yang 
berisi daftar dan alamat KAP disajikan pada Tabel 1. Peneliti memilih di Kantor Akuntan Publik (KAP) di Kota Denpasar agar lebih mudah untuk mendapatkan sampel dan untuk mengetahui konsistensi Kantor Akuntan Publik (KAP) dalam menjaga kualitas audit yang diberikan.

\section{Tabel 1.} Daftar Kantor Akuntan Publik (KAP) di Kota Denpasar

\begin{tabular}{|c|c|c|}
\hline No & Nama Kantor Akuntan Publik & Alamat \\
\hline 1 & KAP Arnaya \& Darmayasa & $\begin{array}{l}\text { Jl. Cargo Indah IIIA, Perum Melang Hill } \\
\text { No. 1, Ubung, Denpasar Utara }\end{array}$ \\
\hline 2 & KAP Budhananda Munidewi & $\begin{array}{l}\text { Jl. Tukad Irawadi No. 18A, Lantai } 2 \& 3 \\
\text { Kelurahan Panjer, Kec. Denpasar Selatan }\end{array}$ \\
\hline 3 & KAP I Wayan Ramantha & Jl. Rampai No. 1A Lantai 3 \\
\hline 4 & KAP Johan Malonda Mustika \& Rekan & Jl. Muding Indah I No. 5, Kerobokan \\
\hline 5 & KAP K. Gunarsa & $\begin{array}{l}\text { Jl. Tukad Banyusari Gang II No. 5, Panjer, } \\
\text { Denpasar }\end{array}$ \\
\hline 6 & KAP Drs. Ketut Budiartha, MSi & $\begin{array}{l}\text { Perumahan Padang Pesona Graha Adhi } \\
\text { Blok A6, Jl. Gunung Agung, Denpasar }\end{array}$ \\
\hline 7 & $\begin{array}{l}\text { KAP Drs. Ketut Muliartha R.M \& } \\
\text { Rekan }\end{array}$ & $\begin{array}{l}\text { Gedung Guna Teknosa Lantai 2, Jl. } \\
\text { Drupadi No. } 25\end{array}$ \\
\hline 8 & $\begin{array}{l}\text { KAP Drs. Sri Marmo Djogosarkono \& } \\
\text { Rekan }\end{array}$ & $\begin{array}{l}\text { Jl. Gunung Muria No. 4, Monang-Maning, } \\
\text { Denpasar }\end{array}$ \\
\hline 9 & KAP Drs. Wayan Sunasdyana & $\begin{array}{l}\text { J1. Pura Demak I Gang IB no. 8, Teuku } \\
\text { Umar Barat, Pemecutan Kelod }\end{array}$ \\
\hline
\end{tabular}

Sumber : IAPI, 2018

Analisis regresi linier berganda digunakan untuk mengetahui pengaruh antara variabel bebas terhadap variabel terikat. Dalam penelitian ini analisis regresi linear berganda digunakan untuk mengetahui besarnya pengaruh independensi, due professional care, akuntabilitas terhadap kualitas audit dengan bantuan program SPSS. Adapun model regresi linear berganda dengan persamaan sebagai berikut.

$$
\mathrm{Y}=\alpha+\beta_{1} X_{1}+\beta_{2} X_{2}+\beta_{3} X_{3}+\mathrm{e}
$$

Keterangan :

$\mathrm{Y}=$ Kualitas Audit

$A=$ Konstanta

$\beta_{1} \beta_{2} \beta_{3}=$ Koefisien regresi variabel $\mathrm{X}_{1} \mathrm{X}_{2} \mathrm{X}_{3}$ 
$\mathrm{X}_{1}=$ Independensi

$\mathrm{X}_{2}=$ Due Professional Care

$\mathrm{X}_{3}=$ Akuntabilitas

$e=$ Error

Selanjutnya akan diamati goodness of fit, yaitu uji $\mathrm{R}^{2}$, uji $\mathrm{F}$, dan uji t.

\section{HASIL DAN PEMBAHASAN}

Statistik deskriptif memberikan gambaran atau deskripsi suatu data yang dilihat dari nilai rata-rata (mean), standar deviasi, varian, maksimum, dan minimum. Nilai mean adalah rata hitung dari suatu data. Hasil statistik deskriptif variabel penelitian dapat disajikan dalam Tabel 2. di bawah ini:

\section{Tabel 2.}

Hasil Uji Statistik Deskriptif

\begin{tabular}{lccccc}
\hline & $\mathrm{N}$ & Minimum & Maximum & Mean & Std. Deviation \\
\hline Independensi & 47 & 21,00 & 28,00 & 24,6383 & 2,89246 \\
Due Professional Care & 47 & 30,00 & 40,00 & 37,5745 & 2,17440 \\
Akuntabilitas & 47 & 31,00 & 40,00 & 37,4255 & 2,61887 \\
Kualitas Audit & 47 & 36,00 & 48,00 & 43,7447 & 4,01339 \\
Valid N (listwise) & 47 & & & & \\
\hline
\end{tabular}

Sumber: Data diolah, 2018

Nilai rata - rata variabel independensi sebesar 24,6383 dengan nilai standar deviasi 2,89246. Hal ini menunjukkan bahwa nilai standar deviasi lebih kecil dari nilai rata - rata dan nilai rata - rata mendekati nilai maksimum. Hal ini mencerminkan bahwa persepsi responden terhadap independensi adalah relatif tinggi.

Nilai rata - rata variabel due professional care sebesar 37,5745 dengan nilai standar deviasi 2,17440. Hal ini menunjukkan bahwa nilai standar deviasi lebih kecil dari nilai rata - rata dan nilai rata - rata mendekati nilai maksimum. Hal ini 
mencerminkan bahwa persepsi responden terhadap due professional care adalah relatif tinggi.

Nilai rata - rata variabel akuntabilitas sebesar 37,4255 dengan nilai standar deviasi 2,61887. Hal ini menunjukkan bahwa nilai standar deviasi lebih kecil dari nilai rata - rata dan nilai rata - rata mendekati nilai maksimum. Hal ini mencerminkan bahwa persepsi responden terhadap akuntabilitas adalah relatif tinggi.

Nilai rata - rata variabel kualitas audit sebesar 43,7447 dengan nilai standar deviasi 4,01339. Hal ini menunjukkan bahwa nilai standar deviasi lebih kecil dari nilai rata - rata dan nilai rata - rata mendekati nilai maksimum. Hal ini mencerminkan bahwa persepsi responden terhadap kualitas audit adalah relatif tinggi. Distribusi data dinyatakan normal jika koefisien Asymp Sig. (2-tailed) yang dihasilkan lebih besar dari 0,05. Adapun hasil uji normalitas dapat diuraikan pada Tabel 3 di bawah ini. 
ISSN: 2302-8556

E-Jurnal Akuntansi Universitas Udayana

Vol.27.3.Juni (2019): 2183-2210

Tabel 3.

Hasil Uji Normalitas

\begin{tabular}{llr}
\hline & & Unstandardized Residual \\
\hline$N$ & & \multicolumn{1}{c}{07} \\
Normal Parameters ${ }^{a, b}$ & Mean & 0,0000000 \\
& Std. Deviation & 2,44893996 \\
Most Extreme Differences & Absolute & 0,085 \\
& Positive & 0,074 \\
& Negative & 0,085 \\
Test Statistic & & 0,085 \\
Asymp. Sig. (2-tailed) & & 0,200 \\
\hline Sumber: Data diolah, 2018 & &
\end{tabular}

Berdasarkan Tabel 3 menunjukkan bahwa nilai Asymp Sig. (2-tailed) sebesar 0,200 > 0,05 yang artinya data penelitian berdistribusi normal maka dapat disimpulkan bahwa model uji telah memenuhi syarat normalitas data.

Uji multikolinearitas dilakukan untuk mengetahui apakah dalam model regresi ditemukan adanya korelasi antar variabel bebas atau tidak. Untuk mengetahui ada tidaknya multikolinearitas dapat dilihat melalui nilai Variance Inflantion Factor (VIF) dan nilai tolerance untuk masing-masing variabel bebas. Apabila nilai tolerance di atas 0,10 dan VIF kurang dari 10 maka dikatakan tidak terdapat gejala multikolonearitas. Adapun hasil uji multikolinearitas disajikan pada Tabel 4 di bawah ini.

Tabel 4.

Hasil Uji Multikolinearitas

\begin{tabular}{llcc}
\hline No. & \multicolumn{1}{c}{ Variabel } & Nilai Tolerance & Nilai VIF \\
\hline 1 & Independensi & 0,485 & 2,064 \\
2 & Due Professional Care & 0,710 & 1,408 \\
3 & Akuntabilitas & 0,700 & 1,428 \\
\hline
\end{tabular}

Sumber: Data diolah, 2018

Berdasarkan Tabel 4 menunjukkan bahwa hasil penghitungan nilai tolerance pada masing-masing variabel penelitian adalah sebesar 0,485 (Independensi), 0,710 
(Due Professional Care) dan 0,700 (Akuntabilitas). Data tersebut menunjukkan tidak ada variabel independen yang memiliki nilai tolerance kurang dari 0,10 yang memiliki arti bahwa tidak ada toleransi antara variabel independen yang nilainya lebih dari 95\%. Tabel 4.8 juga menunjukkan hasil penghitungan nilai VIF (Varian Inflaction Factor) sebesar 2,064 (Independensi), 1,408 (Due Professional Care) dan 1,428 (Akuntabilitas). Data tersebut menunjukkan tidak ada variabel independen yang memiliki nilai VIF > 10. Jadi dapat disimpulkan bahwa tidak ada gejala multikolinearitas antar variabel independen dalam model regresi.

Uji heteroskedastisitas bertujuan untuk menguji apakah dalam model regresi terjadi ketidaksamaan varians dari residual satu pengamatan ke pengamatan yang lain. Jika varians dari residual suatu pengamatan ke pengamatan lain tetap, maka disebut homokedastisitas dan jika berbeda disebut heterokedastisitas. Model regresi yang baik adalah homoskedastisitas. Jika nilai signifikansi berada di atas 0,05 maka model regresi ini bebas dari masalah heteroskedastisitas. Adapun hasil uji heteroskedastisitas disajikan pada Tabel 5 di bawah ini.

\section{Tabel 5.}

\section{Hasil Uji Heteroskedastisitas}

\begin{tabular}{llll}
\hline No & \multicolumn{1}{c}{ Variabel Penelitian } & Sig. & \multicolumn{1}{c}{ Keterangan } \\
\hline 1 & Independensi & 0,120 & Bebas heteroskedastisitas \\
2 & Due Professional Care & 0,792 & Bebas heteroskedastisitas \\
3 & Akuntabilitas & 0,482 & Bebas heteroskedastisitas \\
\hline \multicolumn{2}{l}{ Sumber: Data diolah, 2018 }
\end{tabular}

Berdasarkan Tabel 5 tentang uji heteroskedastisitas dapat diuraikan bahwa nilai signifikansi untuk masing-masing variabel penelitian adalah 0,120 (Independensi), 0,792 (Due Professional Care) dan 0,482 (Akuntabilitas) memiliki 
ISSN: 2302-8556

nilai signifikansi lebih besar dari 0,05. Jadi dapat disimpulkan bahwa tidak terjadi heteroskedastisitas diantara variabel penelitian.

Analisis regresi linear berganda digunakan untuk mengetahui pengaruh antara variabel bebas terhadap variabel terikat. Dalam penelitian ini analisis regresi linear berganda digunakan untuk mengetahui besarnya pengaruh independensi, due professional care, akuntabilitas terhadap kualitas audit. Analisis statistik ini diolah dengan SPSS. Adapun hasil analisis regresi linier berganda disajikan pada Tabel 6 di bawah ini.

\section{Tabel 6.}

Hasil Analisis Regresi Linear Berganda

\begin{tabular}{lccccc}
\hline \multirow{2}{*}{ Variabel } & \multicolumn{2}{c}{$\begin{array}{c}\text { Unstandardized } \\
\text { Coefficints }\end{array}$} & $\begin{array}{c}\text { Standardized } \\
\text { Coefficints } \\
\text { Beta }\end{array}$ & $\mathrm{t}$ & Sig. \\
\hline X1 Independensi & $\mathrm{B}$ & Std. Error & Beta & & \\
X2 Due Professional Care & 0,568 & 0,188 & 0,410 & 3,029 & 0,004 \\
X3 Akuntabilitas & 0,431 & 0,206 & 0,233 & 2,090 & 0,043 \\
Konstanta & 0,406 & 0,172 & 0,265 & 2,354 & 0,023 \\
$R$ Square & \multicolumn{2}{c}{13,490} & & & \\
Fhitung & \multicolumn{2}{c}{0,628} & & & \\
Sig. F hitung & \multicolumn{2}{c}{17,700} & & & \\
\hline
\end{tabular}

Sumber: Data diolah, 2018

Berdasarkan data yang diperoleh dari tabel 7 dapat dilihat nilai koefesien regresi dari variabel bebas independensi, due professional care dan akuntabilitas serta konstanta variabel terikat (kualitas audit), maka diperoleh persamaan regresi linier berganda sebagai berikut:

$$
\begin{aligned}
\mathrm{Y} & =\alpha+\beta_{1}\left(\mathrm{X}_{1}\right)+\beta_{2}\left(\mathrm{X}_{2}\right)+\beta_{3}\left(\mathrm{X}_{3}\right)+\mathrm{e} \\
& =13,490+0,568\left(\mathrm{X}_{1}\right)+0,431\left(\mathrm{X}_{2}\right)+0,406\left(\mathrm{X}_{3}\right)+\mathrm{e}
\end{aligned}
$$


Berdasarkan persamaan tersebut, maka variabel independensi, due professional care dan akuntabilitas berpengaruh terhadap kualitas audit pada Kantor Akuntan Publik di Kota Denpasar.

Besarnya nilai $\alpha$ konstanta sebesar 13,490 mengandung arti jika variabel independensi $\left(\mathrm{X}_{1}\right)$, due professional care $\left(\mathrm{X}_{2}\right)$ dan akuntabilitas $\left(\mathrm{X}_{3}\right)$ tidak berubah, maka kualitas audit (Y) tidak mengalami perubahan atau sama dengan 13,490.

Nilai koefisien $\beta_{1}$ sebesar 0,568 memiliki arti jika variabel independensi $\left(\mathrm{X}_{1}\right)$ mengalami peningkatan, maka akan mengakibatkan peningkatan pada kualitas audit (Y), dengan asumsi variabel bebas lainnya dianggap konstan.

Nilai koefisien $\beta_{2}$ sebesar 0,431 memiliki arti jika variabel due professional care $\left(\mathrm{X}_{2}\right)$ mengalami peningkatan, maka akan mengakibatkan peningkatan pada kualitas audit (Y), dengan asumsi variabel bebas lainnya dianggap konstan.

Nilai koefisien $\beta_{3}$ sebesar 0,406 memiliki arti jika variabel akuntabilitas $\left(\mathrm{X}_{3}\right)$ mengalami peningkatan, maka akan mengakibatkan peningkatan pada kualitas audit (Y), dengan asumsi variabel bebas lainnya dianggap konstan.

Analisis koefisien determinasi bertujuan untuk mengukur seberapa besar variabel bebas mampu menjelaskan perubahan variabel terikatnya. Adapun hasil uji koefisien determinasi $\left(\mathrm{R}^{2}\right)$ disajikan pada tabel 7 .

Tabel 7. Hasil Uji Koefisien Determinasi (Uji R ${ }^{2}$ )

\begin{tabular}{ccccc}
\hline Model & $\mathrm{R}$ & $\mathrm{R}$ Square & $\begin{array}{c}\text { Adjusted } R \\
\text { Square }\end{array}$ & $\begin{array}{c}\text { Std. Error of the } \\
\text { Estimate }\end{array}$ \\
\hline 1 & 0,792 & 0,628 & 0,592 & 2,56290 \\
\hline Sumber: & & & &
\end{tabular}


ISSN: 2302-8556

Berdasarkan data pada Tabel 7 diperoleh angka $\mathrm{R}^{2}$ ( $R$ Square) sebesar 0,628 atau $(62,8 \%)$. Hal ini menunjukkan bahwa persentase sumbangan pengaruh variabel independen (independensi, due professional care dan akuntabilitas) terhadap variabel dependen (kualitas audit) sebesar 62,8\%. Sedangkan sisanya sebesar 37,2\% dipengaruhi atau dijelaskan oleh variabel lain yang tidak dimasukkan dalam penelitian ini.

Uji kelayakan model (uji F) bertujuan untuk mengetahui apakah dalam penelitian ini model yang digunakan layak untuk digunakan atau tidak sebagai alat analasis untuk menguji pengaruh variabel independen terhadap variabel dependen. Tingkat probabilitas yang digunakan adalah 0,05. Apabila taraf signifikan pada tabel annova lebih kecil dari 0,05 maka layak digunakan. Adapun hasil uji kelayakan model (uji F) disajikan pada Tabel 8 di bawah ini:

\section{Tabel 8.}

\section{Hasil Uji Kelayakan Model (Uji F)}

\begin{tabular}{lccc}
\hline \multicolumn{1}{c}{ Model } & Sum of Squares & F & Sig. \\
\hline Regression & 465,060 & 17,700 & 0,000 \\
Residual & 275,876 & & \\
Total & 740,936 & & \\
\hline
\end{tabular}

Sumber: Data diolah, 2018

Berdasarkan Tabel 8 diperoleh nilai dari signifikansi 0,000 yang lebih kecil dari 0,05. Ini berarti bahwa model penelitian ini layak dipergunakan sebagai analisis untuk menguji pengaruh variabel bebas yaitu variabel independensi, due professional care dan akuntabilitas terhadap kualitas audit (variabel terikat).

Uji hipotesis (uji t) dilakukan untuk mengetahui pengaruh dari masing-masing variabel bebas secara parsial terhadap variabel terikat. Apabila nilai sig. $<0,05$ maka 
variabel bebas memiliki pengaruh yang signifikan terhadap variabel terikat. Berdasarkan hasil analisis regresi linier berganda maka hasil analisis Uji-t disajikan pada Tabel 9 di bawah ini:

Tabel 9.

Hasil Uji Hipotesis (Uji t)

\begin{tabular}{llcc}
\hline No. & \multicolumn{1}{c}{ Variabel } & thitung & Signifikansi \\
\hline 1 & Independensi & 3,029 & 0,004 \\
2 & Due Professional Care & 2,090 & 0,043 \\
3 & Akuntabilitas & 2,354 & 0,023 \\
\hline \multicolumn{2}{l}{ Sumber: Data diolah, 2018 }
\end{tabular}

Berdasarkan Tabel 9 tentang uji hipotesis (uji t) dapat diuraikan bahwa nilai thitung dan signifikansi untuk masing-masing variabel penelitian adalah nilai thitung sebesar 3,029 dengan sig 0,004 < 0,05 (independensi), thitung sebesar 2,090 dengan sig $0,043<0,05$ (due professional care) dan thitung sebesar 2,354 dengan sig 0,023<0,05 (akuntabilitas). Hal ini berarti variabel independensi, due professional care, dan akuntabilitas berpengaruh positif dan signifikan terhadap kualitas audit pada Kantor Akuntan Publik di Kota Denpasar.

Hasil pengujian hipotesis variabel independensi menunjukkan nilai thitung sebesar 3,029 dengan nilai sig 0,004 $<0,05$ maka Ho ditolak. Hal ini berarti variabel independensi berpengaruh positif dan signifikan terhadap kualitas audit pada Kantor Akuntan Publik di Kota Denpasar. Hasil penelitian ini bersesuaian dengan Imron dkk., (2017), Tepalagul dan Lin (2015), Usman et al., (2014) dan Hosseinniakani et al., (2014) dalam penelitiannya menyatakan bahwa independensi berpengaruh terhadap kualitas audit. Penelitian ini juga sejalan dengan penelitian yang dilakukan 
ISSN: 2302-8556

(Badjuri, 2011) yang menyatakan bahwa independensi berpengaruh positif terhadap kualitas audit.

Independensi merupakan suatu standar auditing yang sangat penting untuk dimiliki oleh auditor. Auditor harus dapat mempertahankan sikap mental independen karena opini yang dikeluarkannya bertujuan untuk menambah kredibilitas laporan keuangan yang disajikan manajemen, sehingga jika auditor tersebut tidak independen maka kualitas audit yang dihasilkan tidak baik. Independensi digunakan sebagai dasar utama kepercayaan masyarakat terhadap profesi akuntan publik sehingga dalam melaksanakan pekerjaan auditor dituntut untuk bersikap jujur dan tidak memihak. Hal ini sejalan dengan teori yang dikemukakan oleh Mautz dan Sharaf, (1980) yang menyatakan bahwa independensi merupakan sikap auditor yang bebas serta tidak memihak dalam melaksanakan audit.

Hasil pengujian hipotesis variabel due professional care menunjukkan nilai thitung sebesar 2,090 dengan nilai sig 0,043 < 0,05 maka Ho ditolak. Hal ini berarti variabel due professional care berpengaruh positif dan signifikan terhadap kualitas audit pada Kantor Akuntan Publik di Kota Denpasar. Hal ini berarti bahwa kecermatan dan keseksamaan yang dimiliki auditor akan memberikan pengaruh terhadap kualitas audit yang dimiliki auditor dimana hal tersebut akan memberikan suatu kepercayaan yang memadai bahwa laporan keuangan akan bebas dari salah saji material.

Dalam PSAP No. 4 (2001) juga disebutkan kecermatan dan keseksamaan dalam penggunaan kemahiran profesional menuntut auditor untuk melaksanakan 
skeptisme profesional yaitu sikap auditor yang berpikir kritis terhadap bukti audit dengan selalu mempertanyakan dan melakukan evaluasi terhadap bukti audit tersebut. Louwers, et.al (2008) menyatakan bahwa kegagalan audit dalam kasus fraud transaksi pihak-pihak terkait disebabkan oleh kurangnya sikap skeptis dan due professional care auditor daripada kekurangan dalam pemenuhan standar auditing. Penelitian ini sejalan dengan penelitian Ichwanty (2015) dan Faturachman (2015) mengemukakan due professional care berpengaruh positif terhadap kualitas audit.

Penggunaan kemahiran profesional dengan cermat dan seksama memungkinkan auditor untuk memperoleh keyakinan memadai bahwa laporan keuangan bebas dari salah saji material, baik yang disebabkan oleh kekeliruan maupun kecurangan. Seorang auditor harus tetap menjaga sikap skeptis profesionalnya selama proses pemeriksaan, karena ketika auditor sudah tidak mampu lagi mempertahankan sikap skeptis profesionalnya, maka laporan keuangan yang diaudit tidak dipercaya lagi, dan memungkinkan adanya litigasi paska audit. Hasil penelitian Nearon dalam Mansur (2007) menyatakan bahwa jika auditor gagal dalam menggunakan sikap skeptis atau penerapan sikap skeptis yang tidak sesuai dengan kondisi pada saat pemeriksaan, maka opini audit yang diterbitkannya tidak berdaya guna dan tidak memiliki kausalitas audit yang baik.

Hasil pengujian hipotesis variabel akuntabilitas menunjukkan nilai thitung sebesar 2,354 dengan nilai sig 0,023 <0,05 maka Ho ditolak. Hal ini berarti variabel akuntabilitas berpengaruh positif dan signifikan terhadap kualitas audit pada Kantor Akuntan Publik di Kota Denpasar. Hal ini sejalan dengan penelitian yang dilakukan 
ISSN: 2302-8556

Saripudin dkk., (2012) yang menyatakan terdapat pengaruh positif signifikan akuntabilitas terhadap kualitas audit. Hal ini mengindikasikan auditor yang bertanggungjawab terhadap profesi dan karirnya maka akan menyelesaikan tugasnya tepat waktu sehingga hal tersebut dapat meningkatkan kualitas audit.

Akuntabilitas merupakan bentuk dorongan psikologi yang membuat seseorang berusaha mempertanggungjawabkan semua tindakan dan keputusan yang telah diambil kepada lingkungannya. Auditor yang memiliki tanggungjawab yang tinggi tentunya akan berusaha meningkatkan kualitas audit. Hal ini juga sesuai dengan teori yang dikemukakan oleh Nugrahaningsih (2005) yang menyatakan bahwa akuntan memiliki kewajiban untuk menjaga standar perilaku etis tertinggi mereka kepada organisasi dimana mereka berlindung, profesi mereka, masyarakat dan pribadi mereka sendiri dimana akuntan mempunyai tanggung jawab menjadi kompeten dan berusaha menjaga integritas dan obyektifitas mereka. Hasil penelitian ini sejalan dengan hasil penelitian yang dilakukan oleh Mardisar dan Sari (2007), dan Purwanda dan Harahap, (2015) menyatakan bahwa akuntabilitas dapat meningkatkan kualitas hasil kerja auditor.

Melihat begitu pentingnya akuntabilitas seorang auditor maka Ikatan Akuntansi Indonesia menetapkan bentuk tanggung jawab auditor sehingga Standar Profesional Akuntan Publik (SPAP) diantaranya adalah tanggung jawab mendeteksi dan melaporkan kecurangan (fraud), kekeliruan, tanggung jawab mempertahankan sikap indepedensi dan menghindari konflik, tanggung jawab mengkomunikasikan 
informasi yang berguna tentang sifat dan hasil proses audit, tanggung jawab menemukan tindakan melanggar hukum dari klien.

Berdasarkan hasil analisis dan pembahasan hasil penelitian yang ditemukan, terdapat beberapa implikasi berkaitan dengan penelitian yang telah dilakukan. Implikasi dari hasil penelitian ini terdiri dari implikasi teoritis dan implikasi praktis.

Penelitian ini membuktikan secara teoritis, dapat memberikan bukti empiris bahwa indepedensi, due professional care, dan akuntabilitas auditor berpengaruh signifikan terhadap kualitas audit. Hasil penelitian ini dapat digunakan sebagai referensi dan bahan pengembangan penelitian selanjutnya mengenai pengaruh indepedensi, due professional care, dan akuntabilitas auditor pada kualitas audit.

Penelitian ini memberikan hasil bahwa indepedensi, due professional care, dan akuntabilitas auditor berpengaruh signifikan terhadap kualitas audit. Oleh karena itu, pemahaman terhadap indepedensi, due professional care, dan akuntabilitas auditor sebaiknya diterapkan dalam Kantor Akuntan Publik (KAP) dengan cara memberikan pelatihan dan pendidikan yang dapat menambah pengetahuannya dalam profesinya sebagai auditor sehingga kualitas audit yang dihasilkan akan semakin baik.

Kantor Akuntan Publik (KAP) diharapkan dapat menjaga kualitas para auditornya agar dapat menjunjung tinggi dan menjaga kualitas audit sehingga kredibilitas hasil audit di mata pengguna informasi laporan keuangan dapat dijaga. 
ISSN: 2302-8556

E-Jurnal Akuntansi Universitas Udayana

Vol.27.3.Juni (2019): 2183-2210

\section{SIMPULAN}

Independensi berpengaruh positif terhadap kualitas audit pada Kantor Akuntan Publik di Kota Denpasar. Hal ini berarti semakin tinggi independensi auditor akan meningkatkan kualitas audit pada Kantor Akuntan Publik di Kota Denpasar.

Due professional care berpengaruh positif terhadap kualitas audit pada Kantor Akuntan Publik di Kota Denpasar. Hal ini berarti bahwa semakin cermat dan seksama seorang auditor dalam melaksanakan audit, maka kualitas audit akan semakin baik.

Akuntabilitas berpengaruh positif terhadap kualitas audit pada Kantor Akuntan Publik di Kota Denpasar. Hal ini berarti bahwa auditor yang memiliki tanggungjawab yang tinggi tentunya akan menghasilkan kualitas audit yang baik.

Auditor junior seharusnya lebih banyak melakukan konsultasi kepada para auditor senior dalam meminta saran, pendapat dan solusi menangani masalah yang dihadapi dalam melakukan audit. Independensi, sikap profesional dan akuntabilitas yang sudah dimiliki oleh auditor harus tetap dipertahankan bahkan ditingkatkan untuk mempertahankan/meningkatkan kualitas audit. Penelitian yang akan datang diharapkan untuk menambah variabel penelitian yang mempengaruhi kualitas audit seperti pelatihan, semangat kerja dan komitmen individu.

\section{REFERENSI}

Agusti, R., \& Pertiwi, N. P. (2013). Pengaruh Kompetensi, Independensi, dan Profesionalisme Terhadap Kualitas Audit (Studi Empiris Pada Kantor Akuntan Publik Se-Sumatera). Jurnal Ekonomi, 21(September), 1-13. https://doi.org/Volume 21, Nomor 3 September 2013 
Badjuri, A. (2011). Faktor-Faktor yang Berpengaruh terhadap Kualitas Audit Auditor Independen pada Kantor Akuntan Publik (KAP) Di Jawa Tengah Influencing Factors On Independent Auditors Towards Audit Quality in Public Accountant's Offices in Central Java, 3(2), 183-197.

Bawono, I. R., \& Singgih, E. M. (2010). Faktor - Faktor dalam Diri Auditor dan Kualitas Audit: Studi Pada KAP Big Four Di Indonesia. Jurnal Akuntansi Dan Auditing Indonesia, 14(2), 1-20.

Gavious, I. (2007). Alternative perspectives to deal with auditors' agency problem. Critical Perspectives on Accounting, 18(4), 451-467. https://doi.org/10.1016/j.cpa.2006.01.011

Hosseinniakani, S. M., Inácio, H., \& Mota, R. (2014). A review on audit quality factors. International Journal of Academic Research in Accounting, Finance and Management Sciences, 4(2), 243-254. https://doi.org/10.6007/IJARAFMS/v4$\mathrm{i} 2 / 861$

Ichwanty, A. (2015). Pengaruh Kompetensi, Independensi, Due Professional Care, Akuntabilitas, dan Etika terhadap Kualitas Audit (Studi Empiris pada Auditor Kantor Akuntan Publik di Provinsi Riau dan Kepulauan Riau). Jurnal Online Mahasiswa FEKON, 2(2), 1-15.

Ikatan Akuntan Indonesia, I. (2001). Standar Profesional Akuntan Publik. Jakarta, Indonesia: Salemba Empat.

Imron, M. A., Widyastuti, T., \& Amilin. (2017). Pengaruh Pengetahuan Audit , Independensi Dan Audit Investigasi Pada Auditor Inspektorat Jenderal Kementerian Keuangan. Jurnal Ilmiah WIDYA Ekonomika, 1(July), 1-8. https://doi.org/10.7448/17582652.2017.1302679

Kovinna, F., \& Betri. (2009). Pengaruh independensi, pengalaman kerja, kompetensi, dan etika auditor terhadap kualitas audit. Akuntansi.

Louwers, T. J., Henry, E., Reed, B. J., \& Gordon, E. A. (2008). Deficiencies in Auditing Related-Party Transactions: Insights from AAERs. Current Issues in Auditing, 2(2), A10-A16. https://doi.org/10.2308/ciia.2008.2.2.A10

Mansur, T. (2007). Faktor-Faktor yang Mempengaruhi Kualitas Audit Ditinjau dari Persepsi Auditor atas Pelatihan dan Keahlian, Independensi dan Penggunaan Kemahiran Profesional. Universitas Gadjah Mada. 
ISSN: 2302-8556

E-Jurnal Akuntansi Universitas Udayana

Vol.27.3.Juni (2019): 2183-2210

Mardisar, D., \& Sari, R. N. (2007). Pengaruh Akuntabilitas dan Pengetahuan Terhadap Kualitas Hasil Kerja Auditor. Simposium Nasional Akuntansi X.

Mautz R. K, Ph.d., CPA, \& Husein A. Sharaf, P. . (1980). The Philosophy of Auditing (10th ed.). Florida: American Accounting Association.

Mulyadi. (2014). Auditing (6th ed.). Jakarta: Salemba Empat.

Nugraha, M. E. (2012). Pengaruh independensi, kompetensi, dan profesionalisme terhadap kualitas audit. Jurnal Ilmiah Mahasiswa Akuntansi.

Nugrahaningsih, P. (2005). Analisis perbedaan perilaku etis auditor di kap dalam etika profesi (studi terhadap peran faktor-faktor individual: Locus of Control, Lama Pengalaman Kerja, Gender, dan Equity Sensitivity). SIimposium Nasionak Akuntansi VIII, (September), 14.

Prabhawanti, P. P., \& Widhiyani, N. L. S. (2018). Pengaruh Besaran Fee Audit dan Independensi Terhadap Kualitas Audit dan Etika Profesi Auditor Sebagai Moderasi. E-Jurnal Akuntansi UNUD, 24(3 september 2018), 2247-2273.

Priantara, D. (2017). Ketika Skandal Fraud Akuntansi Menerpa British Telecom dan PwC. Retrieved April 1, 2018, from https://www.wartaekonomi.co.id/read145257/ketika-skandal-fraud-akuntansimenerpa-british-telecom-dan-pwc.html

Purwanda, E., \& Harahap, E. A. (2015). Pengaruh Akuntabilitas dan Kompetensi terhadap Kualitas Audit (Survey Pada Kantor Akuntan Publik Di Bandung). Jurnal Akuntansi, XIX(03), 357-369.

Purwaningsih, Ratna, A., \& Animah, E. P. (2015). Pengaruh Kompetensi, Independensi, Due Professsional Care dan Motivasi terhadap Kualitas Audit (Studi Empiris pada Inspektorat se-pulau Lombok). Jurnal Ekonomi Dan Bisnis, 9(3), 12.

Saripudin, Herawaty, N., \& Rahayu. (2012). Pengaruh independensi, pengalaman, due professional care dan akuntabilitas terhadap kualitas audit (survei terhadap auditor KAP di jambi dan palembang). E-Jurnal Binar Akuntansi. https://doi.org/10.1007/s11069-013-0777-9

Syafina, D. C. (2018). Kasus SNP Finance dan Pertaruhan Rusaknya Reputasi Akuntan Publik. Retrieved October 8, 2018, from https://tirto.id/kasus-snpfinance-dan-pertaruhan-rusaknya-reputasi-akuntan-publik-c4RT 
Tb. Aman Faturachman, A. N. (2015). Pengaruh Due Professional Care Terhadap Kualitas Audit Pada Kantor Akuntan Publik Di Kota Bandung. Jurnal Riset Akuntansi Dan Keuangan Program Studi Akuntansi Fakultas Pendidikan Ekonomi Dan Bisnis Universitas Pendidikan Indonesia, 3(1), 562-571. https://doi.org/http://dx.doi.org/10.17509/jrak.v3i1.6604

Tepalagul, N., \& Lin, L. (2015). Auditor Independence and Audit Quality: A Literature Review. Journal of Accounting, Auditing and Finance, 30(1), 101121. https://doi.org/10.1177/0148558X14544505

Usman, A., e Sudarma, M., Habbe, H., \& Said, D. (2014). Effect of Competence Factor, Independence and Attitude against Professional Auditor Audit Quality Improve Performance in Inspectorate (Inspectorate Empirical Study in South Sulawesi Province). IOSR Journal of Business and Management, 16(1), 01-13. https://doi.org/10.9790/487X-16120113 